EESTI NSV TEADUSTE AKADEEMIA TOIMETISED 1955. IV kd., nr. 1 ИЗВЕСТИЯ АКАДЕМИ И НАУК ЭСТОНСКОИ ССР 1955. ТоМ IV, № 1

\title{
КЕРАМЗИТ НА БАЗЕ МЕСТНОГО СЫРЬЯ
}

\author{
К. И. КАСK
}

Среди строительных материалов немаловажное значение имеют легкие бетоны, применение которых позволяет сооружать теплые, гигиеничные жилища, а также сельскохозяйственные производственные здания с утепленными полами и потолками. Однако применение легких бетонов в Эстонской ССР не получило пока широкого распространения из-за отсутствия на месте качественных заполнителей бетона. Но в последнее время доказано, что из местных легкоплавких глин можно изготовлять искусственный легкий материал - керамзит.

Керамзит в виде гранул различной величины может применяться в качестве заполнителя легких бетонов - керамзитобетонов, а также как насыпной теплоизоляционный материал.

Работами советских ученых, особенно исследовательскими работами, проведенными за последние годы в Институте строительной техники Академии архитектуры СССР, установлена возможность изготовления керамзитового гравия из глин, обладающих соответствующими свойствами.

Изучение возможности изготовления керамзнтового гравия из местных легкоплавких глин и разработка технологии его изготовления проводились в 1950-1953 гг. в Институте энергетики Академии наук ЭССР. Исследования позволили установить полную возможность изготовления керамзитового гравия из некоторых четвертичных глин республики. Исследованию были подвергнуты четвертичные глины Хаапсалуского, Кингисеппского и Вана-Вигалаского месторождений. Глина Хаапсалуского месторождения залегает в окрестностях г. Хаапсалу неоднородными пластами толщиной от 1,5 до 6,5 м. Для изготовления керамзита оказались пригодными только верхние пласты глины. Залежи глины Кингисеппского месторождения не изучены, хотя ее образцы и показали пригодность для изготовления керамзита. Залежи глины Вана-Вигалаского месторождения находятся вблизи станции Вигала железной дороги Таллин-Виртсу. По данным Института геологии АН ЭССР, глина залегает мошным пластом, достигая в центре очага глубины 11,5 м. Верхние слои, до глубины 2,53,0 м, смешаны с песком; следующне слон, до глубины 11,5 м, образуют пласт чистой, однородной, пластичной глины, пригодной для изготовления керамзита.

Изготовление керамзита основано на использовании свойств некоторых глин вспучиваться при обжиге. Вспучивание глины объясняется процессом восстановления окислов железа с выделением газообразных продуктов в момент размягчения обжигаемой глиняной массы. При этом счи- 
тается, что глина, пригодная в качестве сырья для изготовления керамзита, должна иметь повышенное содержание окислов железа, порядка $6-8 \%$, и содержать, кроме того, в достаточном количестве органические включения. Физико-химическая сущность взаимодействия окислов железа и органических веществ выражается в том, что при температурах свыше $1000^{\circ}$ окислы железа высших степеней окисления под действием восстановителей (углерод органических веществ) переходят в низшую степень окисления - закись железа, легко реагирующую с другими минералами глины, образуя легкоплавкие ферроалюминиевые силикаты. В результате этого глинистая масса приобретает некоторую подвижность, достаточную для того, чтобы давление газообразных продуктов взаимодействия окислов железа и восстановителей, а также газообразных продуктов диссоциации и разложения глинистых минералов произвело эффект вспучивания.

Данные о содержании окислов железа, кальция и магния в глинах Хаапсалуского, Қингисеппского и Вана-Внгалаского месторождений приведены в таблице 1.

Таблица 1

Содержание окислов железа, кальция и магния в глинах Хаaпcалуского, Кингисеппского и Вана-Вигалаского месторождений (в \%)

\begin{tabular}{|c|c|c|c|}
\hline $\begin{array}{c}\text { Месторождение, шурф, } \\
\text { слой }\end{array}$ & $\mathrm{Fe}_{2} \mathrm{O}_{3}+\mathrm{FeO}$ & $\mathrm{CaO}$ & $\mathrm{MgO}$ \\
\hline $\begin{array}{l}\text { Хаапсалуское, шурфы } 19 \text { и } 25 \\
\text { Хаапсалуское, шурф } 4 \text {, слой I } \\
\text { Хаапсалуское, шурф } 4 \text {, слой II } \\
\text { Хаапсалуское, шурф } 4 \text {, слой III } \\
\text { Вана-Вигалаское } \\
\text { Вана-Вигалаское, образец } 417 \\
\text { Вана-Вигалаское, образец } 423 \\
\text { Вана-Вигалаское, образец } 426 \\
\text { Қингисеппское, верхний слой } \\
\text { Кингисеппское, нижний слой }\end{array}$ & $\begin{array}{c}7,8 \\
7,1 \\
8,0 \\
9,1 \\
7,06 \\
9,4 \\
11,5 \\
10,2 \\
8,74 \\
11,7\end{array}$ & $\begin{array}{l}2,4 \\
2,1 \\
2,6 \\
1,8 \\
1,74 \\
2,1\end{array}$ & $\begin{array}{l}2,75 \\
2,0 \\
3,1 \\
3,2 \\
315 \\
17\end{array}$ \\
\hline
\end{tabular}

При мечание. Анализы проведены лабораторией технического анализа Института промышленных проблем АН ЭССР (телерь Институт энергетики).

Данные таблицы показывают, что все глины указанных месторождений имеют в своем составе достаточное количество окислов железа. Однако не все эти глины пригодны для изготовления керамзита. Опыты по изготовлению керамзита в лабораторных электрических печах показали, что из кингисеппской и вана-вигалаской глин получался керамзит хорошего качества, причем процесс вспучивания протекал быстро и легко *. Обратное наблюдалось при обжиге хаапсалуской глины. Из глины верхних пластов получался керамзит более или менее удовлетворительного качества, а из глины средних и нижних пластов получить керамзит удовлетворительного качества зачастую не удавалось. Әто обстоятельство указывает на то, что для оценки качества́ глины как сырья недостаточно знать только содержание в глине окислов железа. Кроме химического анализа, необходимо определить содержание в глине механических примесей в виде песка и мелкораспределенного гумуса. Опыты показали, что содержание в глине песка уменьшает возможность вспучивания глины при обжиге, а

* На возможность легкого вспучивания глины Вана-Вигалаского месторождения обратил внимание автора доктор геолого-минералогических наук Н. Л. Дилакторский (Институт строительства и строительных материалов АН ЭССР); ему же автор признателен и за ряд ценных советов в ходе исследования. 
чрезмерное его содержание вообе исключает возможность вспучивания глины.

Существенное значение для вспучивания глины имеет содержание в ней органических включений. Определение количественного содержания органических веществ в глине крайне затруднительно. Для сравнительных оценок глин отдельных месторождений по содержанию органических включений можно пользоваться определением количества углекислоты $\left(\mathrm{CO}_{2}\right)$, получаемой при сжигании глины в струе кислорода. При этом определении из общего количества $\mathrm{CO}_{2}$ следует вычесть количество $\mathrm{CO}_{2}$, выделенное углекислыми солями кальция и магния ( $\mathrm{CO}_{2}$-минер.). Остаток и будет углекислотой, выделенной органическими веществами ( $\mathrm{CO}_{2}$-орг.). Таким образом, определение сводится к следующему:

а) Определяется содержание $\mathrm{CO}_{2}$-минер. Это достигается действием $8 \%$ соляной кислоты на навеску тонкоизмельченной глины при слабом ее нагревании. Выделившаяся $\mathrm{CO}_{2}$-минер. улавливается в трубках с едким кали и фосфорным ангидридом. Привес этих трубок и дает процент содержания $\mathrm{CO}_{2}$-минер. в пробе глины.

б) Определяется $\mathrm{CO}_{2}$-орг. путем сжигания навески глины в струе кислорода в присутствии перекиси свинца, при температуре $650-680^{\circ}$. По привесу трубок с едким кали и хлористым кальцием определяется содержание $\mathrm{CO}_{2}$-орг. и частично $\mathrm{CO}_{2}$-минер., образовавшееся от разложения при этих температурах углекислых солей кальция и магния.

в) Определяется $\mathrm{CO}_{2}$-минер. в прокаленной навеске, образовавшееся из частично неразложившихся углекислых солей кальция и магния. Это количество $\mathrm{CO}_{2}$-минер. определяется путем обработки навески $8 \%$ соляной кислотой аналогично определению по пункту а.

Процентное содержание углекислоты органического происхождения получим, сложив данные определений по пунктам б и в и вычтя данные определения по пункту а, что можно условно обозначить формулой

$$
\mathrm{CO}_{2} \text {-орг. }=6+8-a \text {. }
$$

Сравнительные данные о содержании углекислоты как органического, так и минерального происхождения в глинах Вана-Вигалаского и Хаапсалуского месторождений приведены в таблице 2.

Таблица 2

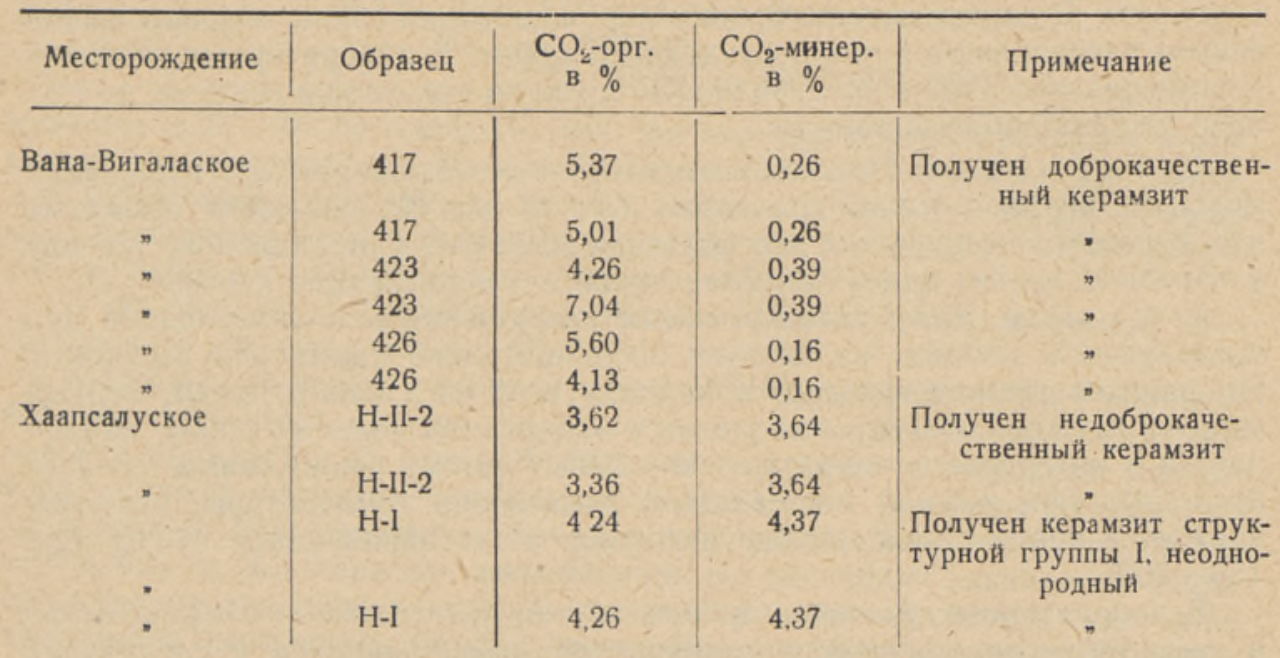

Пр и ме ч а и е. Определение органических веществ в глине проведено кандидатом технических наук Н. К. Поликарповым (Институт энергетики АН ЭССР). 
Анализ данных таблицы 2 показывает, что вана-вигалаская глина, дающая керамзит хорошего качества, содержит больше органических включений, чем хаапсалуская глина, не дающая доброкачественного керамзита. Кроме того, вана-вигалаская глина содержит незначительное количество углекислых солей кальция и магния, тогда как хаапсалуская глина содержит их в значительном количестве. При введении в состав вана-вигалаской глины углекислых солей кальция в виде мелкоразмолотого мела (в количестве до $5 \%$ ) глина при обжиге на керамзит не давала качественного продукта; получалась неоднородно вспученная масса, имеющая внутри черный цвет, которая по внешнему виду во многом напоминала образцы, полученные при обжиге нижних слоев хаапсалуской глины.

То обстоятельство, что химический состав показывает большее содержание солей кальция и магния, чем это получено при определении углекислых солей этих элементов, дает основание предполагать, что в глине, особенно Вана-Вигалаского месторождения, кальций и магний входят главным образом-в состав минералов глины.

Неблагоприятное влияние примеси песка на образование керамзита проверялось обжигом проб глины Хаапсалуского месторождения (пробы глин по отдельным пластам глубины буровых скважин были получены из Института геологии АН ӘССР) и сопоставлением качества полученных продуктов с характеристикой глины каждого пласта на содержание песка. Соответствующие данные приведены в таблице 3.

Поскольку глина Вана-Вигалаского месторождения, как сырье для изготовления керамзита, обладает хорошими качествами, то в основу разработки технологии изготовления керамзитового гравия и была взята глина данного месторождения.

Процесс изготовления керамзитового гравия можно разбить на следующие операции: подготовка сырья, формовка, сушка, обжиг и охлаждение получаемого продукта.

При лабораторном исследовании эти операции выполнялись следующим образом.

1. Под гото в к а сы р я. Так как глина Вана-Вигалаского месторождения является четвертичной глиной слоистого строения, то требуется интенсивное перемешивание ее при обработке на сырье для изготовления керамзита. В случае недостаточного перемешивания глины образцы любой формы расслаиваются при последующей сушке. В лабораторных условиях перемешивание глины производилось вручную при увлажнении ее до степени удобообрабатываемости.

2. Форм в ка. После тщательного перемешивания из глины формовались вручную шары диаметром 25-35 мм. Исследование показало, что форма шара является для образцов нанболее рациональной, так как ý образцов других форм остаются грани, не образующие керамзит.

3. С ушка. Для предотвращения разрушения глиняных шаров при последующем обжиге, их следует предварительно тщательно высушить. По данным термографического анализа вана-вигалаской глины, первый эндотермический эффект, связанный с испарением воды из глины, наблюдается в интервале температур $100-130^{\circ}$. Поэтому сушку шаров следует проводить при режиме постепенного повышения температуры, перекрывающей в конце сушки данный интервал, т. е. заканчивать сушку при $150-200^{\circ}$.

В лабораторных условиях процесс сушки проводился последовательно в трех термостатах, причем температура выдерживалась в следующих пределах: в первом термостате $-65-70^{\circ}$, во втором $-90-100^{\circ}$ и в третьем - 150-160․ Исследование процесса сушки испытуемых образцов 
Характеристика обжига глины Хаапсалуского месторождения

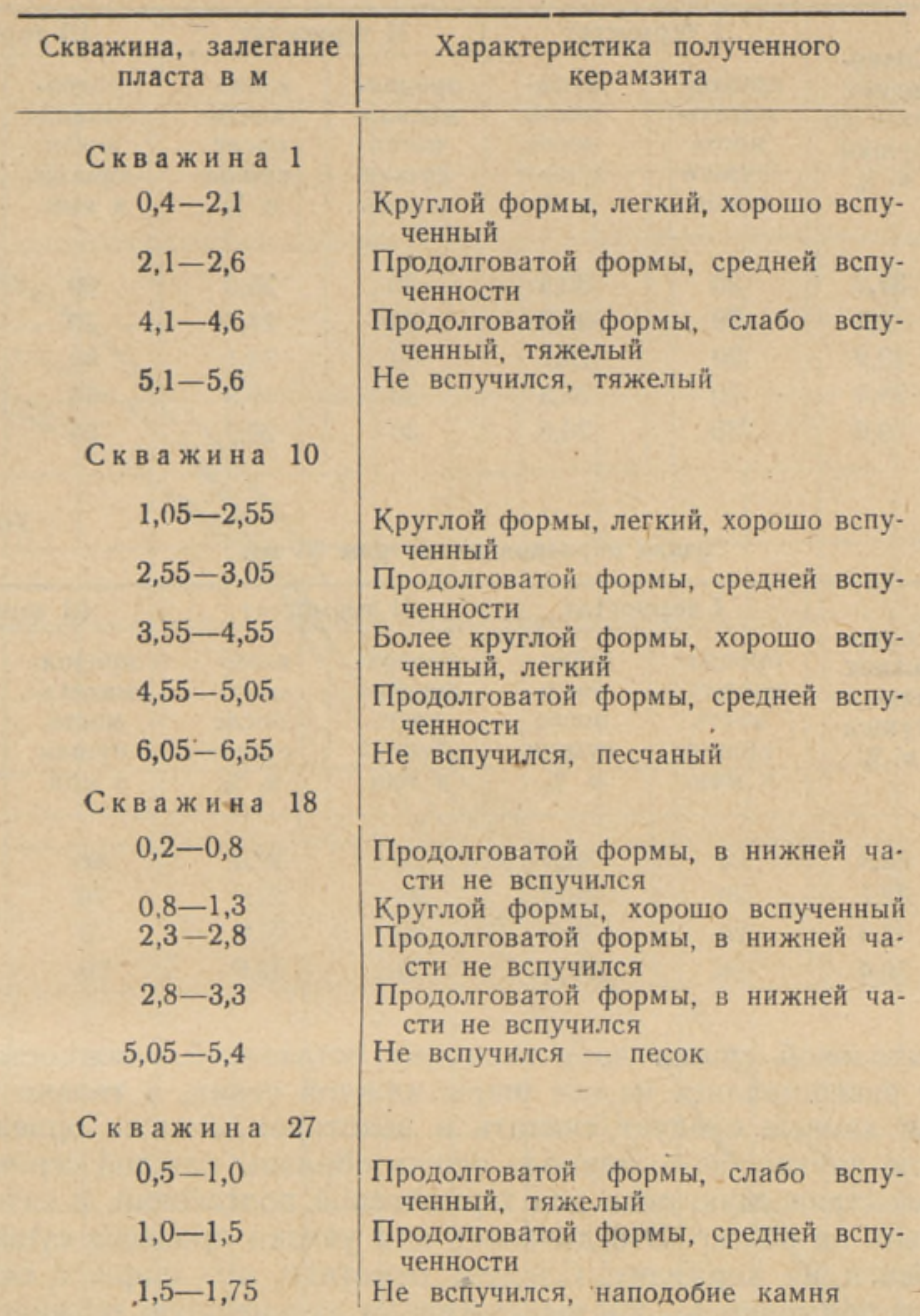

диаметром 28-35 мм показало, что при ведении сушки в условиях повышающейся температуры процесс сушки можно закончить за 120 минут, при остаточной влажности в среднем около 4-5\%. При этом оптимальная продолжительность сушки была: в первом термостате - 20-30 минут, во втором - 30 минут и в третьем - 60-70 минут.

В таблицах 4 и 5 приведены данные о сушке образцов диаметром 25 28 мм и 35 мм (фиг. 1 и и 16 ).

Выдержка образцов в термостатах производилась следующим образом. Все три термостата находились рядом, и перестановка проволочных корзинок с образцами из одного термостата в другой происходила быстро. Каждая серия образцов состояла из 16-18 шаров, примерно одинаковых по величине. При переноске образцов из одного термостата в другой исключалось по три шара для взвешивания. По окончании двухчасового процесса сушки от одного до трех шаров каждой серии оставлялись до окончательного высыхания, которое отмечалось постоянством веса. Уменьшение веса шаров за период сушки, как в каждом термостате, так и во всех термостатах, отражает выделение влаги из образцов. Уменьшение веса 
Сушка образцов диаметром 25-28 мм

Таблица 4

\begin{tabular}{|c|c|c|c|c|c|c|c|}
\hline \multirow[b]{2}{*}{$\begin{array}{c}\text { Марки- } \\
\text { ровка } \\
\text { серии } \\
\text { образцов }\end{array}$} & \multirow[b]{2}{*}{$\begin{array}{c}\text { Содер- } \\
\text { жание } \\
\text { влаги до } \\
\text { сушки } \\
\text { в \% }\end{array}$} & \multicolumn{2}{|c|}{ I термостат } & \multicolumn{2}{|c|}{ II термостат } & \multicolumn{2}{|c|}{ III термостат } \\
\hline & & $\begin{array}{c}\text { продол- } \\
\text { житель- } \\
\text { ность } \\
\text { сушки } \\
\text { в мин. }\end{array}$ & $\begin{array}{c}\text { влаж- } \\
\text { ность } \\
\text { после } \\
\text { сушки } \\
\text { в \% }\end{array}$ & $\begin{array}{c}\text { продол- } \\
\text { житель- } \\
\text { ность } \\
\text { сушки } \\
\text { в мин. }\end{array}$ & $\begin{array}{c}\text { влаж- } \\
\text { ность } \\
\text { после } \\
\text { сушки } \\
\text { в \% }\end{array}$ & $\begin{array}{c}\text { продол- } \\
\text { житель- } \\
\text { ность } \\
\text { сушки } \\
\text { в мин. }\end{array}$ & $\begin{array}{c}\text { влаж- } \\
\text { ность } \\
\text { после } \\
\text { сушки } \\
\text { в \% }\end{array}$ \\
\hline B-392 & 32,2 & 20 & 30,4 & 20 & 25,3 & 60 & 5,0 \\
\hline B-396 & 32,1 & 20 & 30,2 & 30 & 24,2 & 70 & 3,5 \\
\hline B-390 & 29,9 & 20 & 28,7 & 30 & 23,1 & 60 & 2,6 \\
\hline B-388 & 28,2 & 30 & 25,8 & 30 & 19,9 & 60 & 4,1 \\
\hline B-389 & 29,0 & 30 & 26,0 & 30 & 20,9 & 60 & 7,4 \\
\hline
\end{tabular}

Сушка образцов диаметром 35 мм

Таблица 5

\begin{tabular}{|c|c|c|c|c|c|c|c|}
\hline \multirow[b]{2}{*}{$\begin{array}{c}\text { Марки- } \\
\text { ровка } \\
\text { серии } \\
\text { образцов }\end{array}$} & \multirow[b]{2}{*}{$\begin{array}{c}\text { Содер- } \\
\text { жание } \\
\text { влаги до } \\
\text { сушки } \\
\text { в \% }\end{array}$} & \multicolumn{2}{|c|}{ I термостат } & \multicolumn{2}{|c|}{ II термостат } & \multicolumn{2}{|c|}{ III термостат } \\
\hline & & $\begin{array}{c}\text { продол- } \\
\text { житель- } \\
\text { ность } \\
\text { сушки } \\
\text { в мин. }\end{array}$ & $\begin{array}{c}\text { влаж- } \\
\text { ность } \\
\text { после } \\
\text { сушки } \\
\text { в \% }\end{array}$ & $\begin{array}{c}\text { продол- } \\
\text { житель- } \\
\text { ность } \\
\text { сушки } \\
\text { в мин. }\end{array}$ & $\begin{array}{c}\text { влаж- } \\
\text { ность } \\
\text { после } \\
\text { сушки } \\
\text { в \% }\end{array}$ & $\begin{array}{c}\text { продол- } \\
\text { житель- } \\
\text { ность } \\
\text { сушки } \\
\text { в мин. }\end{array}$ & $\begin{array}{c}\text { влаж- } \\
\text { ность } \\
\text { после } \\
\text { сушки } \\
\text { в \% }\end{array}$ \\
\hline B-393 & 32,4 & 20 & 30,8 & 20 & 27,4 & 60 & 8,4 \\
\hline B-394 & 32,1 & 20 & 30,3 & 30 & 22,9 & 70 & 3,9 \\
\hline B-398 & 32,3 & 20 & 30,2 & 30 & 23,8 & 70 & 3,1 \\
\hline B-397 & 30,4 & 20 & 29,0 & 30 & 22,6 & 70 & 3,2 \\
\hline
\end{tabular}

после двухчасовой сушки дает величину остаточной влажности шаров. Поскольку взвешивались не все шары каждой серии, а только часть, то полученные данные следует считать в некотором смысле ориентировочными. После двухчасового периода сушки образцы каждой серии переносились в электрическую печь для термической подготовки, а затем в следующую печь на обжиг. Это делалось для увязки процесса сушки с процессом обжига на керамзит. Следует отметить, что шары с остаточной влажностью примерно 4-5\% выдерживали дальнейшую термическую обработку, в то время как шары с повышенной влажностью большей частью разрушались.

4. О бжи г ша ров н а кер а м и т. При изготовлении керамзита глиняные шары после процесса сушки следует термически подготовить к обжигу. Термическая подготовка заключается в их прогреве до известной температуры, после чего шары можно внести в среду с температурой обжига. Если после сушки исключить термическую подготовку, то при последующем обжиге все образцы разрушатся до пылевидного состояния.

Тепловой режим обжига глины на керамзит предусматривает замедленное повышение температуры в зоне подогрева шаров и резкий переход от зоны подогрева к зоне обжига.

В лабораторных условиях обжиг проводился последовательно в трех электрических печах, причем зону подогрева составляли две қамерные электрические печи ңа $800^{\circ}$ (с нихромовыми нагревателями), а зону обжига камерная электрическая печь на $1350^{\circ}$ (с силитовыми нагревателями). Температура электрической печи с силитовыми нагревателями регулировалась_автоматически с точностью до $\pm 10^{\circ}$. 


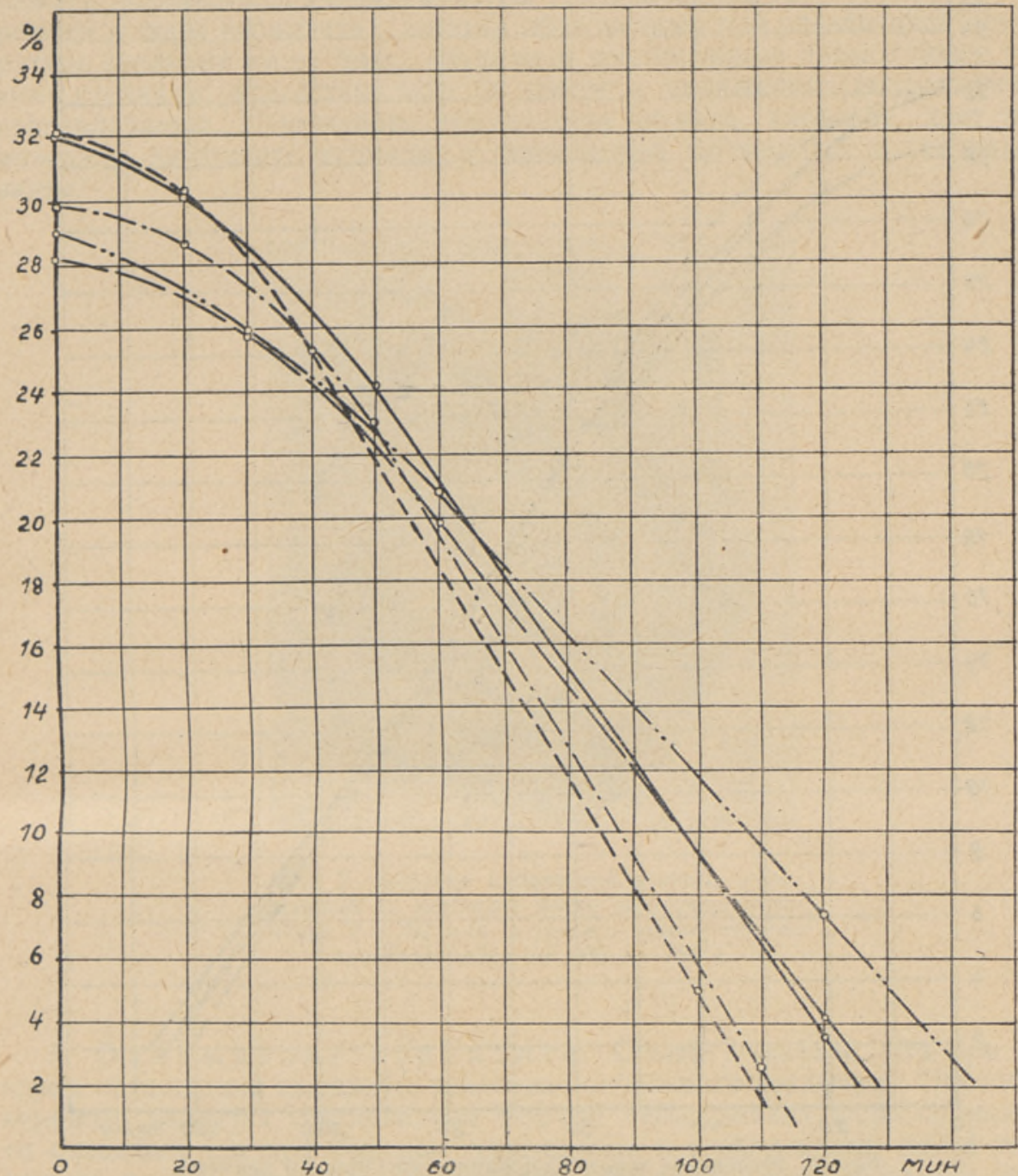

Фиг. 1. Изменение влагосодержания образцов во времени. $a$ - шары диаметром 25-28 мм.

Исследование показало зависимость качества получаемого керамзита от продолжительности подогрева и температуры как в зоне подогрева, так и в зоне обжига.

Чрезмерно длительный подогрев при температуре свыше $500^{\circ}$ приводит к образованию на поверхности глиняного шара корочки, толщина которой увеличивается по мере продолжительности подогрева (фиг. 2). Подогрев глиняных шаров при температуре $350-400^{\circ}$ не дал существенных изменений, исключая изменение серого цвета в серокоричневый. Материал, полученный дроблением этих шаров, пригоден для их повторного изготовления. 


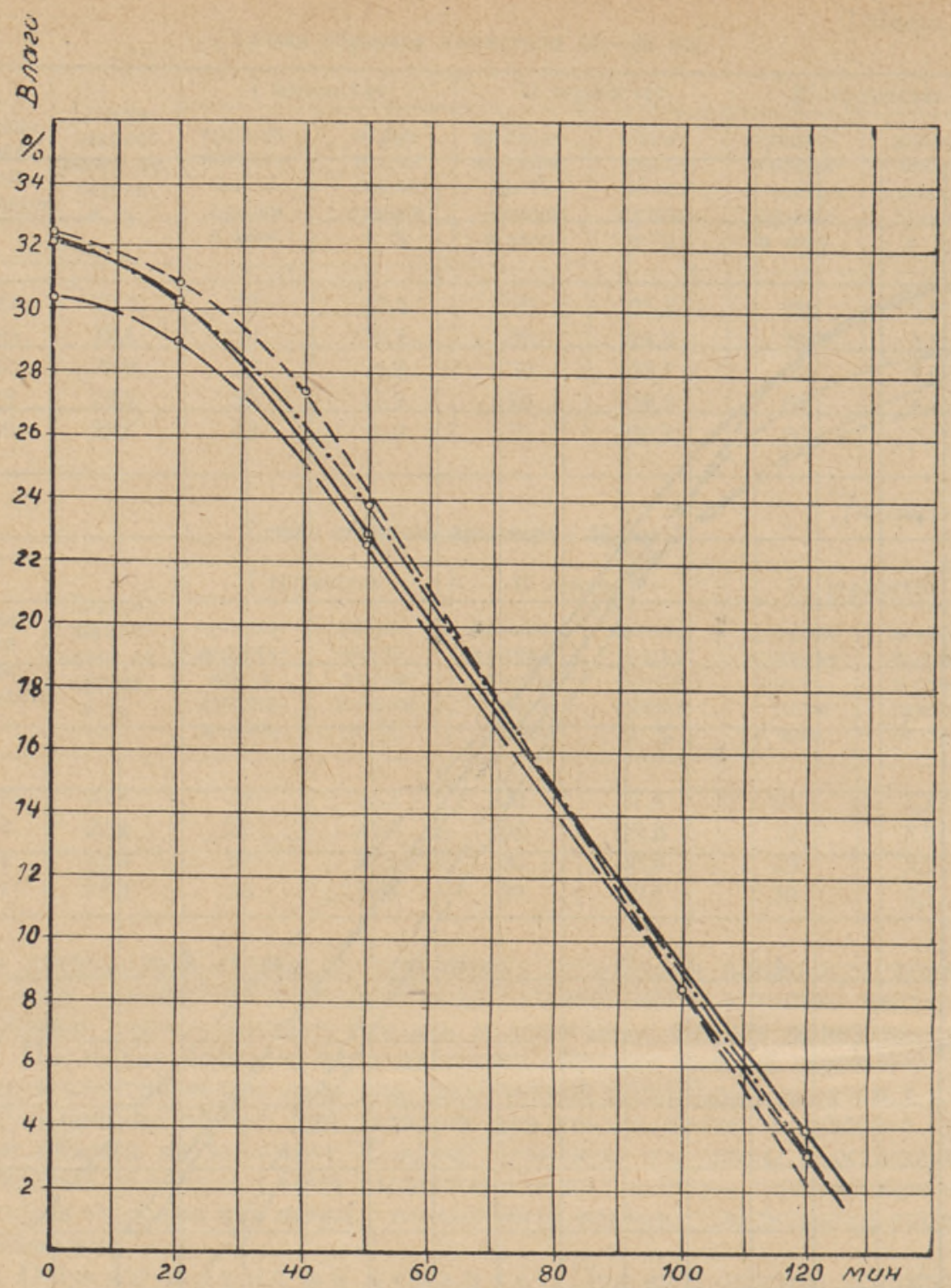

Фиг. 1. Изменение влагосодержания образцов во времени. 6 - шары диаметром 35 мм.

Лабораторные опыты показали, что шары диаметром 30-35 мм из глины Вана-Вигалаского месторождения необходимо предварительно термически обрабатывать в течение $35-40$ минут при температуре от 250 до $700^{\circ}$. В лабораторных условиях это достигалось тем, что термическая подготовка (в процессе обжига - пребывание в зоне подогрева) разбивалась на две ступени: первая ступень - подогрев образцов в одной электрической печи при температуре $250-350^{\circ}$; вторая ступень - подогрев во второй электрической печи при температуре $650-680^{\circ}$. В первой печи шары выдерживались 20 минут и быстро перекладывались во вторую печь на $15-20$ минут.

После термической подготовки шары переносились на обжиг в печь, 
где они выдерживались от 10 до 20 минут. Исследования показали, что наилучшие результаты получались при температуре обжига 1050-1080. При температуре обжига $1050-1060^{\circ}$ выдержка во времени - 15-20 минут, при температуре $1080^{\circ}-10$ минут. При более высокой температуре обжига подвижность глиняной массы увеличивается, за счет чего расширяются и поры керамзита. Поэтому обожженный при завышенной температуре керамзит имеет более крупные и неодинаковые поры с более тонкими стенками, вследствие чего он имеет и пониженное сопротивление раздавливанию. Пониженная температура обжига, наоборот, дает возможность изготовить керамзит с повышенной прочностью на раздавливание.

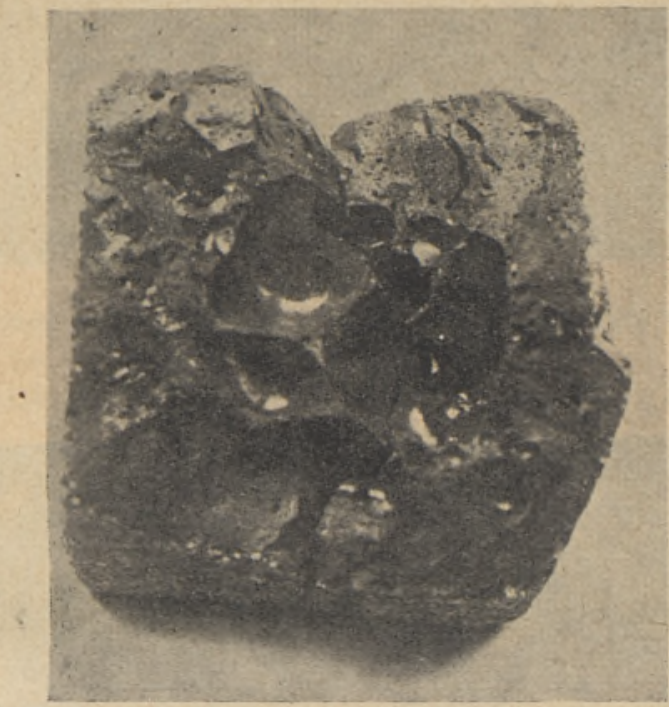

Фиг. 2. Образец кубической формы, обожженный на керамзит после подогрева в течение 2 ч. 50 мин. в среде с температурой, повышающейся от 200 до $750^{\circ} \mathrm{C}$.

5. Охлаждение керамзита. Опыты показали, что при быстром охлаждении снижается качество получаемого керамзита. Поскольку керамзит является стекловидной формой легкоплавких ферросиликатов, то очевидно, что при быстром охлаждении в стекловидной массе появляются мелкие трещины, значительно снижающие сопротивление материала раздавливанию. Полученный керамзит следует охлаждать до температуры окружаћщего воздуха медленно, примерно в течение двух-трех часов. В лабораторных условиях охлаждение керамзита происходило в электрической камерной печи с силитовыми нагревателями, которая выключалась из сети после загрузки в нее при температуре $1000^{\circ}$ свежеобожженного керамзита.

Исследованием выявлена зависимость качества получаемого керамзита от продолжительности обжига и температуры среды, в которой происходит обжиг.

Полученный керамзит в зависимости от степени расплавления входящих в его состав минералов в процессе его образования имеет различное строение: различной величины поры, различной толщины стенки пор, на- 


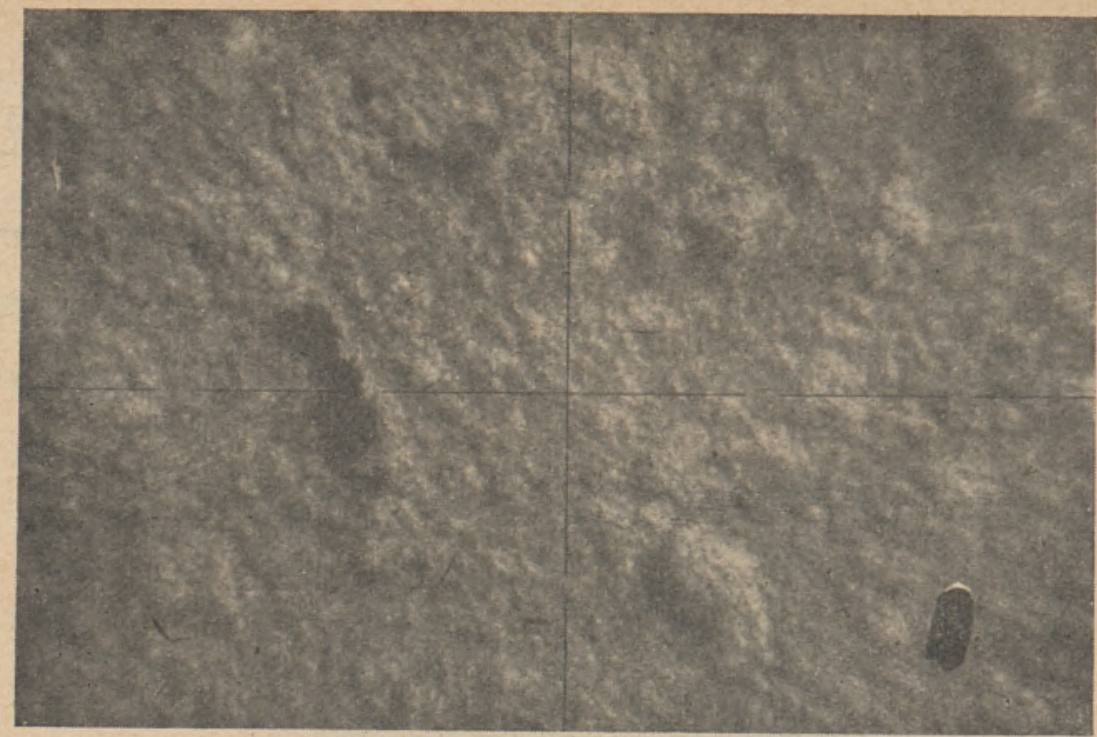

Фиг. 3. Қерамзит структурной группы IV-V, пригодный в качестве заполнителя бетонов. Увеличение в 20 раз.

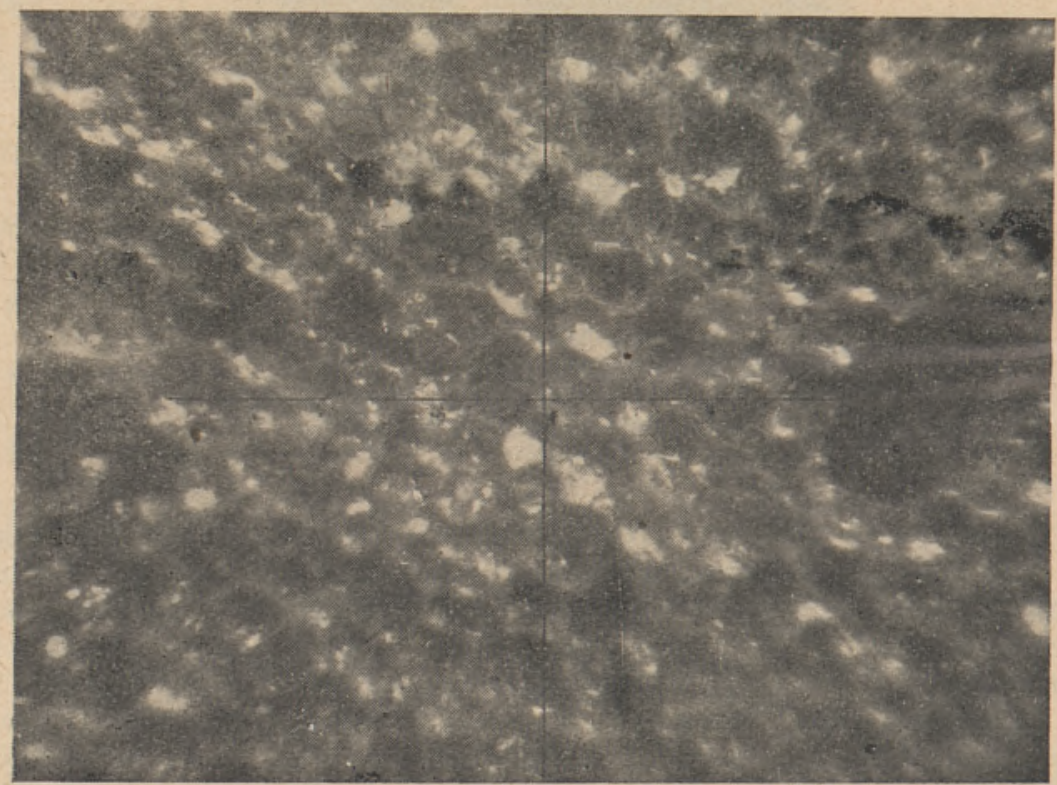

Фиг. 4. Керамзит структурной группы II, пригодный в качестве теплоизоляционного материала. Увеличение в 20 раз.

личие однородной или неоднородной структуры. Это различие в строении керамзита обусловливает и различные качественные показатели отдельных групп керамзита.

Полученный лабораторным путем керамзит разбивался на структурные группы (фиг. 3 и 4). 
Из показателей определялись:

1) объемный вес $\left(г / \mathrm{cm}^{3}\right)$ в куске, как с корочкой, так и без корочки,

2) сопротивление раздавливанию в кг $/ \mathrm{cm}^{2}$ (на выпиленных из керамзита кубиках размером $2 \times 2 \times 2 \mathrm{~cm}$ ),

3) водопоглощение в процентах, как холодным способом, так и кипячением,

4) морозостойкость (количество циклов: замораживание-оттаивание).

В таблице 6 приведены их значения для керамзитового гравия, полученного лабораторным путем.

Таблица 6

Качественные показатели керамзитового гравия

\begin{tabular}{|c|c|c|c|c|c|c|c|}
\hline \multirow{2}{*}{$\begin{array}{l}\text { Струк- } \\
\text { турная } \\
\text { группа }\end{array}$} & \multicolumn{2}{|c|}{$\begin{array}{c}\text { Объемный вес в } \\
\mathrm{r} / \mathrm{cm}^{3}\end{array}$} & \multirow{2}{*}{$\begin{array}{c}\text { Сопротивле- } \\
\text { ние раздав- } \\
\text { ливанию } \\
\text { в кг } / \text { см }^{2}\end{array}$} & \multicolumn{2}{|c|}{$\begin{array}{c}\text { Водопоглощение } \\
\text { (холодный способ) в \% }\end{array}$} & \multirow{2}{*}{$\begin{array}{l}\text { Водопо- } \\
\text { глощение } \\
\text { (кипяче- } \\
\text { нием) в \% }\end{array}$} & \multirow{2}{*}{$\begin{array}{c}\text { Морозостой- } \\
\text { кость (коли- } \\
\text { чество } \\
\text { циклов) }\end{array}$} \\
\hline & $\begin{array}{c}\text { с короч- } \\
\text { кой }\end{array}$ & $\begin{array}{c}\text { без } \\
\text { корочки }\end{array}$ & & $\begin{array}{l}\text { с короч- } \\
\text { кой }\end{array}$ & $\begin{array}{c}\text { без } \\
\text { корочки }\end{array}$ & & \\
\hline I & $0,2-0,5$ & $0,2-0,3$ & $8-38$ & $7,8-9$ & $27-66$ & $36-68$ & - \\
\hline II & $0,2-0,5$ & $0,2-0,4$ & $13-45$ & $5,2-8$ & $16-58$ & $18-50$ & $\begin{array}{l}\text { не ниже } 25 \\
\text { циклов }\end{array}$ \\
\hline IV & $0,35-0,7$ & $0,37-0,5$ & $40-75$ & $4,6-8$ & $18-26$ & $22-35$ & 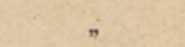 \\
\hline V & $0,7-1,25$ & $0.8-1,0$ & 100 и более & $2-4$ & - & - & - \\
\hline Пемза & - & $0,5-0,6$ & $20-25$ & - & $60-70$ & $100-150$ & - \\
\hline
\end{tabular}

Исследованием выявлено, что при изготовлении керамзитового гравия пластическим методом следует исходить из следующих требований:

1. Глина должна иметь в своем составе не менее $7-8 \%$ окислов железа, минимальное количество углекислых солей кальция и магния $\left(\mathrm{CO}_{2}\right.$-минер. не более $\left.0,5 \%\right)$ и достаточное количество органических включений (в переводе на $\mathrm{CO}_{2}$-орг. не менее $4-5 \%$ ), но не должна содержать механических примесей в виде песка.

2. Сушку глиняных шаров следует проводить до остаточной влажности $4-5 \%$ примерно в течение двух часов, при начальной температуре $65-75^{\circ}$ и конечной температуре $150-200^{\circ}$.

3. Термическая подготовка высушенных образцов должна протекать 35 - 40 минут от начальной температуры $200-250^{\circ}$ до конечной температуры $650-700^{\circ}$.

4. Продолжительность обжига должна составлять примерно $15-20$ минут при температуре порядка $1050-1080^{\circ}$.

5. Полученный керамзит следует охлаждать в течение $2-3$ часов до температуры окружающего воздуха.

При соблюдении этих условий из глин месторождений Эстонской ССР можно изготовлять доброкачественный керамзит.

Ннститут энергетики
Академии наук Эстонской ССР

Поступила в редакцню

16 IX 1954

\section{ЛИТЕРАТУРА}

С. П. О н а ц к й, Керамзитовый гравий, Москва, 1953. 